\title{
Variability in phosphite sensitivity observed within and between seven Phytophthora species
}

\author{
Shannon Hunter ${ }^{1,2}$ D $\cdot$ Rebecca McDougal $^{1} \cdot$ Nari Williams $^{1,3} \cdot$ Peter Scott $^{1,4}$
}

Received: 7 October 2021 / Accepted: 21 December 2021 / Published online: 11 January 2022

(c) The Author(s) 2021

\begin{abstract}
Phosphite is used to control and manage many phytophthora diseases in horticultural systems worldwide and natural ecosystems in Australia, Africa, New Zealand and parts of Northern America and Europe. Phosphite does not kill Phytophthora species, but inhibits growth while also stimulating host defence responses. Phytophthora species differ in their underlying tolerance to phosphite and isolates have been shown to acquire tolerance after prolonged exposure. Intra- and inter-specific variability in phosphite sensitivity is of interest to determine the efficacy and sustainability of phosphite for the treatment of phytophthora diseases, which continue to spread globally. Seven Phytophthora species were tested for their sensitivity to phosphite in vitro in a mycelial growth experiment. Phytophthora agathidicida was the species most sensitive to phosphite, being inhibited by $98.7 \%$ on average at the lowest phosphite treatment (15 $\mu \mathrm{g} / \mathrm{mL}$ phosphite), followed by P. aleatoria, P. cinnamomi, P. pluvialis, P. multivora, $P$. kernoviae and P. citricola. Huge intraspecific variability was observed with $P$. kernoviae, which raises the question of whether diseases caused by $P$. kernoviae such as phytophthora needle blight of Pinus radiata could be managed effectively with phosphite. Further work is required to determine the phosphite sensitivity of different introduced and native Phytophthora species growing in key hosts and whether tolerance observed in vitro is also expressed in vivo.
\end{abstract}

Keywords Phytophthora $\cdot$ Phosphite $\cdot$ Interspecific $\cdot$ Intraspecific Variability $\cdot$ Mangement

\section{Introduction}

Phytophthora diseases are commonly managed using phosphite in agricultural and natural settings (Hardy et al. 2001). In New Zealand, phosphite is widely used in most commercial nurseries and orchards to manage avocado root rot caused by Phytophthora cinnamomi. Phosphite has been proposed as a potential management option for red needle cast of Pinus radiata caused by $P$. pluvialis (Dick et al. 2014). It is also being explored for use to control kauri dieback caused

Shannon Hunter

Shannon.Hunter@plantandfood.co.nz

1 Forest Protection, Scion Research, Titokorangi Drive, Whakarewarewa, Rotorua 3010, New Zealand

2 Plant and Food Research, 120 Mt Albert Road, Sandringham, Auckland 1025, New Zealand

3 Plant and Food Research, Cnr Crosses and St Georges Roads, Havelock North 4130, New Zealand

4 Department of Primary Industries and Regional Development, 3 Baron-Hay Court, South Perth, WA 6151, Australia by $P$. agathidicida (Bradshaw et al. 2020). Understanding the phosphite sensitivity of Phytophthora species is important as phosphite is one of few available chemical treatments to manage new and introduced species, which are spreading due to globalisation and trade (Scott et al. 2019).

Phosphite works directly on Phytophthora by inhibiting growth and sporulation, and also stimulates host defence responses (Smillie et al. 1989; Guest et al. 2010). Phytophthora species differ in their sensitivity to phosphite (Coffey and Bower 1984) and isolates can acquire tolerance to phosphite after prolonged exposure (Wilkinson et al. 2001; Dobrowolski et al. 2008; Ma and McLeod 2014; Hunter et al. 2018; Hunter 2018). This prompts concerns about the future efficacy of phosphite to control Phytophthora diseases, especially in horticultural systems where phosphite has been used for extended periods of time already. Significant research has been conducted into the molecular, genetic and biochemical mechanisms underlying phosphite control of phytophthora diseases (Eshraghi et al. 2011; Lim et al. 2013; Burra et al. 2014). Understanding how different Phytophthora species and isolates acquire phosphite tolerance will help determine the mechanisms of phosphite-induced control of Phytophthora pathogens. 
This study assessed inter- and intraspecific variability in the in vitro phosphite sensitivity of seven Phytophthora species present in New Zealand.

\section{Materials and methods}

\section{Experimental design}

Phosphite sensitivity was tested across six concentrations of phosphite $(0,15,40,80,200$ and $500 \mu \mathrm{g} / \mathrm{mL})$ using an optical density assay (Hunter 2018).

\section{Phytophthora isolate sampling and culture}

Phytophthora isolates from the New Zealand Forest Research Institute Culture Collection (NZFS) at Scion Research (Table 1) were maintained in water vials at $4{ }^{\circ} \mathrm{C}$ on carrot agar. Isolates were subcultured into $90 \mathrm{~mm}$ Petri dishes containing $20 \mathrm{~mL}$ liquid broth of modified Ribeiro's Minimal Medium (RMM) (Ribeiro et al. 1975), modified as outlined below. The glucose concentration was $9.0 \mathrm{~g} / \mathrm{L}$ and $\beta$-sitosterol was omitted. MES hydrate buffer (2-(N-morpholino) ethanesulfonic acid) was added at a final concentration of $0.03 \mathrm{M}$ and the $\mathrm{pH}$ adjusted to 6.2 with $\mathrm{KOH} 3 \mathrm{M}$. The inoculum plates were stored at $20{ }^{\circ} \mathrm{C}$ in the dark.

\section{Phosphite amendment}

Agri-Fos ${ }^{\circledR} 600$ (Agrichem, Yatala QLD, Australia), a commercial potassium phosphite fungicide containing $600 \mathrm{~g} / \mathrm{L}$ phosphorous acid present as mono- and di-potassium phosphonate, was used as the phosphite source for this study. The phosphite was filtered using $0.22 \mu \mathrm{m}$ pore filters (Millex ${ }^{\circledR}-\mathrm{GV}$, Millipore Corporation, Bedford, MA, USA) then added to autoclaved media that had cooled to approximately $50{ }^{\circ} \mathrm{C}$.

\section{Phosphite medium}

Growth experiments were conducted in 24-well microtiter plates (Corning, New York, United States), containing $2 \mathrm{~mL}$ of RMM amended with phosphite in each well. The wells were randomised for inoculation in each replicate block.
Table 1 Phytophthora species, hosts and collection details for isolates used in this study

\begin{tabular}{llllll}
\hline Phytophthora species & NZFS $^{\text {a }}$ & Host & Substrate & Crosby region & Collection date \\
\hline P. agathidicida & 3118 & Agathis australis & Rhizosphere soil & Auckland & $11 / 03 / 2009$ \\
& 3813 & A. australis & Rhizosphere soil & Coromandel & $30 / 01 / 2014$ \\
P. aleatoria & 3815 & A. australis & Rhizosphere soil & Coromandel & $30 / 01 / 2014$ \\
& 4037 & Pinus radiata & Root Collar & Nelson & $14 / 08 / 2014$ \\
P. cinnamomi & 4040 & P. radiata & Branch & Nelson & $14 / 08 / 2014$ \\
& 3034 & P. radiata & Cuttings & Bay of Plenty & $26 / 06 / 2008$ \\
P. citricola & 3750 & P. radiata & Soil and roots & Nelson & $9 / 01 / 2013$ \\
& 3784 & P. radiata & Soil and roots & Nelson & $19 / 01 / 2013$ \\
P. kernoviae & 4460 & Persea americana & Soil and roots & Bay of Plenty & $15 / 2 / 2017$ \\
& 4461 & P. americana & Soil and roots & Bay of Plenty & $15 / 2 / 2017$ \\
& 4462 & P. americana & Soil and roots & Bay of Plenty & $15 / 2 / 2017$ \\
& 3610 & P. radiata & Needle & Auckland & $22 / 06 / 2011$ \\
& 3680 & P. radiata & Needles & Bay of Plenty & $17 / 05 / 2011$ \\
P. multivora & 4053 & P. radiata & Needles & Bay of Plenty & $9 / 10 / 2014$ \\
& $4470^{\text {d }}$ & P. americana & Soil and roots & Coromandel & $27 / 2 / 2017$ \\
& 3866 & A. australis & Soil & N/A & $9 / 05 / 2014$ \\
& 3871 & A. australis & Soil & N/A & $9 / 05 / 2014$ \\
& 3913 & A. australis & Soil & N/A & $9 / 05 / 2014$ \\
& 4019 & P. radiata & Needles & Gisborne & $25 / 08 / 2014$ \\
& 4234 & P. radiata & Needles & Nelson & $12 / 08 / 2015$ \\
\hline
\end{tabular}

$\mathrm{a}=$ New Zealand Forest Service, culture collection reference number

$\mathrm{b}=$ Crosby regions are regions of New Zealand with similar biological and climatic characteristics (Crosby et al. 1998)

$\mathrm{c}=$ Phytophthora citricola isolates were isolated from an avocado orchard (Hunter 2018) which has used phosphite to manage avocado root rot for 32 years via annual injection of all trees with Agrifos 600 . Declining trees received an additional injection

$\mathrm{d}=$ Phytophthora kernoviae isolate 4470 was isolated from an organic avocado orchard which has no recorded use of phosphite 
A $2 \mathrm{~mm}$ diameter circle was cut from the growing margin of a five-day-old mycelial mat in liquid RMM broth and used to inoculate the wells. A control well was included on each plate, containing the amended broth with no isolates. Optical density measurements at $620 \mathrm{~nm}$ (OD620) were taken 13 days after inoculation using the Polar Star Galaxy Microplate Reader (BMG Lab Technologies, Offenburg, Germany). For each well, 32 measurements were taken at consistent locations, and the average OD620 was used as the final value. The plates were stored at $20^{\circ} \mathrm{C}$ in the dark.

\section{Data analysis}

Data analysis was carried out in $\mathrm{R}$ (version 3.6.3). The phosphite response data of the isolates were analysed using a four-parameter log-logistic model with the $\mathrm{R}$ package drc (Ritz et al. 2016). The Effective Concentration (EC) to inhibit growth by 50\% (EC50) and 90\% (EC90) were predicted. The isolates $P$. agathidicida $(3118,3813$ and 3815$)$, P. aleatoria (4040) and P. kernoviae (4470 and 4053), did not fit any of the models in the drc package; however, all isolates were used for the cluster analysis.

A K-means clustering analysis was used to determine the variability in phosphite tolerance within and between the Phytophthora isolates (package 'cluster', Maechler (2019)). Using the percentage growth inhibition at 200 and $500 \mu \mathrm{g} / \mathrm{mL}$ phosphite, we specified three clusters, seeking to force a classification into three groups (phosphite sensitive, intermediate and tolerant).

Percentage growth inhibition was calculated for each replicate based on the average growth for the respective control. The average OD value of the control wells (0.084) was subtracted from the growth measurements for all of the replicates.

\section{Results}

Phytophthora agathidicida was the most sensitive to phosphite, being inhibited by $98.7 \%$ on average at the lowest phosphite treatment of $15 \mu \mathrm{g} / \mathrm{mL}$ phosphite, followed by $P$.

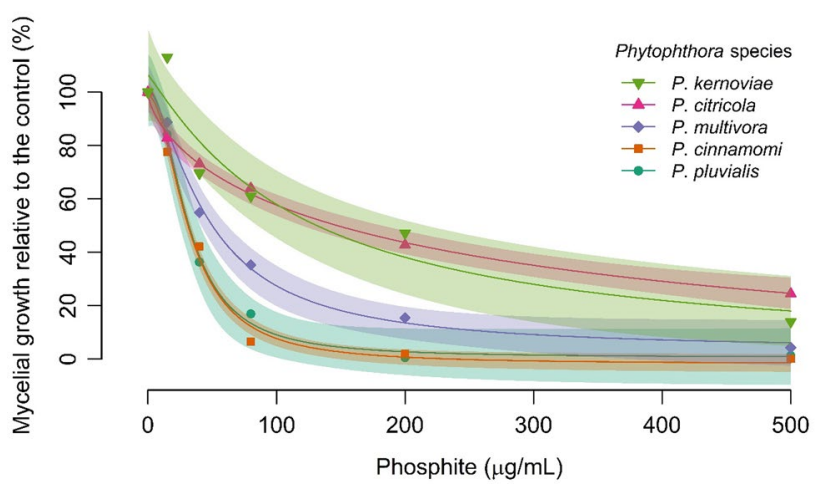

Fig. 1 Response curves showing the average mycelial growth inhibition relative to phosphite concentration of $0 \mu \mathrm{g} / \mathrm{mL}$ for Phytophthora kernoviae, P. citricola, P. multivora, P. cinnamomi and $P$. pluvialis, comprising isolates listed in Table 1, at six phosphite concentrations: $0,15,40,80,200$ and $500 \mu \mathrm{g} / \mathrm{mL}$. Mycelial growth was measured using an optical density assay (Hunter 2018). Bars represent the $95 \%$ confidence intervals for a four-parameter log-logistic model, developed using the R package drc (Ritz et al. 2016). Data omitted for $P$. agathidicida and $P$. aleatoria as the model did not converge

aleatoria, P. cinnamomi, P. pluvialis, P. multivora, P. kernoviae and P. citricola.

Inter-specific variability was observed between $P$. kernoviae and $P$. citricola compared with $P$. cinnamomi, $P$. multivora, and $P$. pluvialis (Fig. 1). Specifically, isolates of $P$. kernoviae and P. citricola were the least sensitive to phosphite, followed by P. multivora (Fig. 1). Phytophthora aleatoria, P. cinnamomi, P. pluvialis and P. multivora had low EC50 and EC90 values compared with P. citricola and P. kernoviae (Table 2). P. agathidicida values would have been even lower, but could not be calculated.

There was no intraspecific variation in the phosphite sensitivity of P. cinnamomi, P. citricola, and P. pluvialis based on the isolates used (Fig. 2). There was intra-specific variability in the phosphite tolerance of the $P$. kernoviae and $P$. multivora isolates (Fig. 2). The intra-specific variability was also shown by the K-means clustering analysis (Fig. 3 and Table 3).
Table 2 Mean phosphite EC50 and EC90 values for the five Phytophthora species fitted to a four parametric log-logistic response curve ( $\mathrm{R}$ package drc, Ritz et al. (2016))

\begin{tabular}{|c|c|c|c|c|}
\hline \multirow[b]{2}{*}{ Phytophthora Species ${ }^{\mathrm{a}}$} & \multicolumn{2}{|c|}{$\operatorname{EC50}^{\mathrm{b}}(\mu \mathrm{g} / \mathrm{mL})$} & \multicolumn{2}{|c|}{$\operatorname{EC90}^{c}(\mu \mathrm{g} / \mathrm{mL})$} \\
\hline & Estimate & Standard Error & Estimate & Standard Error \\
\hline P. cinnamomi & 32.1 & 1.85 & 97.39 & 9.81 \\
\hline P. pluvialis & 33.63 & 6.20 & 103.72 & 39.60 \\
\hline P. multivora & 46.68 & 7.30 & 204.71 & 78.56 \\
\hline P. kernoviae & 118.04 & 114.24 & 864.1 & 1583.68 \\
\hline P. citricola & 146.64 & 70.83 & 2118.81 & 2068.60 \\
\hline
\end{tabular}

a Phytophthora agathidicida was omitted because the sensitivity was so high it did not converge with the model. One of the P. aleatoria did not converge with the model so no average could be calculated at the species level

${ }^{\mathrm{b}}$ The effective concentration to inhibit growth by $50 \%$

${ }^{\mathrm{c}}$ The effective concentration to inhibit growth by $90 \%$ 


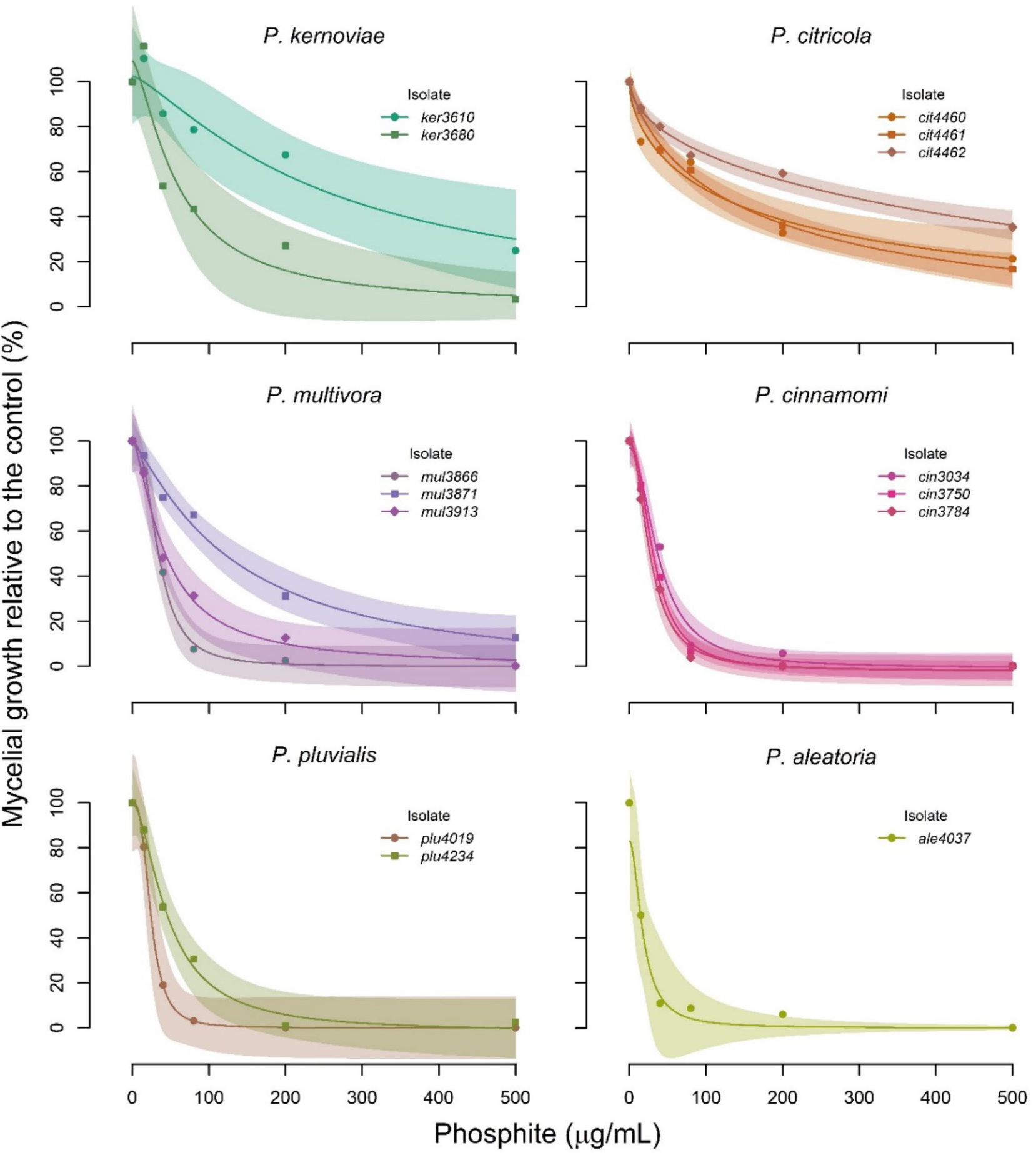

Fig. 2 Response curves showing the average inhibition, or mycelial growth relative to phosphite concentration of $0 \mu \mathrm{g} / \mathrm{mL}$, for Phytophthora kernoviae, $P$. citricola, $P$. multivora, P. cinnamomi, $P$. pluvialis and $P$. aleatoria, comprising isolates listed in Table 1, at six phosphite concentrations $0,15,40,80,200$ and $500 \mu \mathrm{g} / \mathrm{mL}$. Mycelial

The P. citricola isolates with a known history of phosphite exposure (Table 1) grouped as intermediately tolerant in the K-means analysis (Fig. 3). Mycelial growth of isolate 4462 was promoted on some concentrations, resulting in a growth was measured using an optical density assay (Hunter 2018). Bars represent the 5\% confidence intervals for a four-parameter loglogistic model (R package drc, Ritz et al. (2016)). Phytophthora agathidicida was omitted because it did not converge with the model as it was extremely sensitive

high EC50 value (Table 3). The P. agathidicida isolates were extremely sensitive to phosphite, being inhibited by $98.7 \%$ on average by $15 \mu \mathrm{g} / \mathrm{mL}$ and by over $99.8 \%$ at the phosphite concentrations of $40-500 \mu \mathrm{g} / \mathrm{mL}$. 


\section{Discussion}

Inter- and intraspecific variability was observed in this study. This has implications for the efficacy of phosphite as a method to control phytophthora diseases. Also, we do not pay enough attention to variation in the biology within different species, including un-identified and non-described species. For example, there is good evidence that established populations of some Phytophthora species have more variation in pathogenicity than other species (Hüberli et al. 2001; Vernière et al. 2004). Further research is required to understand the variation in susceptibility to phosphite of different isolates within different species.

Land managers need to consider the biology, ecology and historic exposure to phosphite when determining the value of phosphite for managing phytophthora diseases caused by different species and isolates. Our results showed large error bars for the EC50 values of some isolates, which might reflect the natural variation in phosphite susceptibility between species and within isolates. For some isolates, phosphite increased growth. Further work is required to understand this variation in growth behaviour. Screening a set of isolates that reflect the diversity of Phytophthora species within New Zealand and the environments in which they occur, both pathogenic and non-pathogenic, will give a broader understanding of phosphite sensitivity and efficacy.

Table 3 Effective concentration (EC50 and EC90 estimates and standard errors), and Kmeans cluster analysis, of the Phytophthora species outlined in Table 1. Effective concentration values fitted to a four-parameter log-logistic model (R package drc, Ritz et al. (2016).

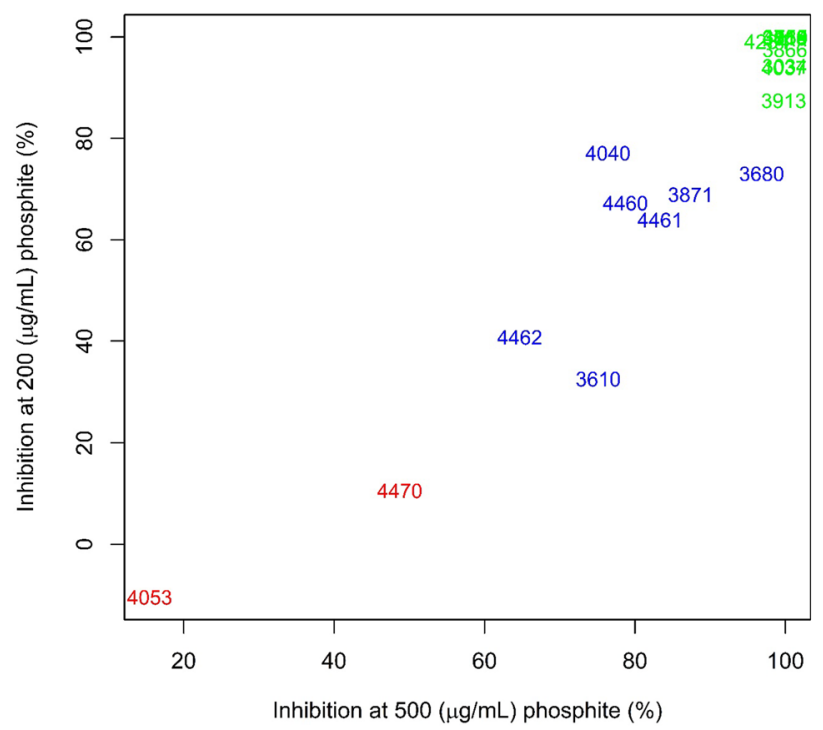

Fig. 3 K-means cluster analysis (R package cluster, Maechler (2019)) of the Phytophthora isolates outlined in Table 1, based on percentage growth inhibition at 200 and $500 \mu \mathrm{g} / \mathrm{mL}$ phosphite relative to the control. Groups $1($ red $)=$ tolerant, 2 (blue) $=$ intermediate, and $3($ green $)=$ susceptible

Phytophthora agathidicida was highly sensitive to phosphite, being inhibited almost completely by the lowest phosphite concentration of $15 \mu \mathrm{g} / \mathrm{ml}$. This validates previous

$\mathrm{NA}=$ no data available and corresponds to isolates where the models did not converge. K-means cluster analysis ( $\mathrm{R}$ package cluster, Maechler (2019) based on percentage growth inhibition at 200 and $500 \mu \mathrm{g} / \mathrm{mL}$ phosphite relative to the control and represented in Fig. 3

\begin{tabular}{|c|c|c|c|c|c|c|}
\hline \multirow[t]{2}{*}{ Species } & \multirow[t]{2}{*}{ Isolate } & \multicolumn{2}{|c|}{$\operatorname{EC50}(\mu \mathrm{g} / \mathrm{mL})$} & \multicolumn{2}{|c|}{ EC90 $(\mu \mathrm{g} / \mathrm{mL})$} & \multirow[t]{2}{*}{ Kmeans cluster group } \\
\hline & & Estimate & Standard Error & Estimate & Standard Error & \\
\hline P. agathidicida & 3118 & NA & NA & NA & NA & Susceptible \\
\hline P. agathidicida & 3813 & NA & NA & NA & NA & Susceptible \\
\hline P. agathidicida & 3815 & NA & NA & NA & NA & Susceptible \\
\hline P. aleatoria & 4040 & NA & NA & NA & NA & Intermediate \\
\hline P. aleatoria & 4037 & 18.11 & 6.21 & 55.43 & 40.42 & Susceptible \\
\hline P. pluvialis & 4019 & 24.38 & 5.28 & 51.80 & 18.09 & Susceptible \\
\hline P. cinnamomi & 3784 & 27.57 & 3.13 & 83.59 & 16.44 & Susceptible \\
\hline P. cinnamomi & 3750 & 31.94 & 2.11 & 88.93 & 10.00 & Susceptible \\
\hline P. multivora & 3866 & 34.46 & 4.62 & 81.46 & 19.45 & Susceptible \\
\hline P. cinnamomi & 3034 & 38.45 & 3.86 & 113.52 & 22.77 & Susceptible \\
\hline P. multivora & 3913 & 42.35 & 11.15 & 198.87 & 130.12 & Susceptible \\
\hline P. kernoviae & 3680 & 44.11 & 19.42 & 129.83 & 137.80 & Intermediate \\
\hline P. pluvialis & 4234 & 46.69 & 9.43 & 168.28 & 74.63 & Susceptible \\
\hline P. multivora & 3871 & 130.87 & 52.33 & 813.86 & 755.58 & Intermediate \\
\hline P. citricola & 4461 & 162.12 & 105.58 & 2328.93 & 2987.53 & Intermediate \\
\hline P. citricola & 4460 & 179.00 & 235.36 & 4389.62 & 11325.11 & Intermediate \\
\hline P. kernoviae & 3610 & 410.73 & 697.63 & 3077.09 & 8391.38 & Intermediate \\
\hline P. citricola & 4462 & 2269.85 & 7291.39 & 126490.20 & 543634.80 & Intermediate \\
\hline P. kernoviae & 4053 & NA & NA & NA & NA & Tolerant \\
\hline P. kernoviae & 4470 & NA & NA & NA & NA & Tolerant \\
\hline
\end{tabular}


work in which an EC50 value of $4.0 \mu \mathrm{g} / \mathrm{mL}$ phosphite was predicted for $P$. agathidicida, which was also more sensitive than P. cinnamomi and P. cactorum (Horner and Hough 2013). Forest trials on kauri trees infected with $P$. agathidicida showed dramatic healing of trunk lesions after trunk injections with $7.5-20 \%$ phosphite (Horner et al. 2015). These studies showed the potential to use phosphite to manage kauri dieback. Caution should be taken against relying on phosphite as the only means to control phytophthora diseases as there is potential for Phytophthora species to acquire resistance to phosphite (Dobrowolski et al. 2008).

In our study, $P$. kernoviae showed the greatest intraspecific variation. In the United Kingdom, P. kernoviae causes disease in some forest tree and ornamental species (Brasier et al. 2005) and foliar necrosis in native heathland communities of Vaccinium myrtillus (Beales et al. 2009). Phytophthora kernoviae is believed to have been present in New Zealand for at least 70 years (Ramsfield et al. 2009) and has been isolated infrequently from Pinus radiata needles with red needle cast symptoms (Dick et al. 2014). Phytophthora kernoviae is thought to be the causal agent of a previously undiagnosed disorder of pine, called physiological needle blight (McDougal and Ganley 2021).

The zoospores of P. kernoviae isolates 3610 and 3680 in the current study were also used to inoculate phosphitetreated Pinus radiata needles and test mycelial growth inhibition (Rolando et al. 2017). The phosphite treatments were 15,30 , and $60 \mathrm{~g} / \mathrm{L}$ phosphite of Agrifos 600 (Roland et al. 2017). It is unsurprising that mycelial growth (in an in vitro mycelial inhibition assay) was completely inhibited by the high concentrations tested by Rolando et al. (2017), considering they were inhibited in the current study in which the highest concentration tested was equivalent to $0.5 \mathrm{~g} / \mathrm{L}$.

The $P$. cinnamomi isolates in the current study were all from Pinus radiata plantations and were consistently sensitive to phosphite. A previous study by Coffey and Bower (1984) also found P. cinnamomi to be sensitive to phosphite, relative to other Phytophthora species. This is interesting when we consider how several studies have found isolates can gain tolerance to phosphite after prolonged exposure (Wilkinson et al. 2001; Dobrowolski et al. 2008; Ma and McLeod 2014; Hunter et al. 2018; Hunter 2018), emphasising the potential scale of acquired resistance in P. cinnamomi from horticultural settings. Further work is required to determine how phosphite resistance persists within an ecosystem after phosphite application has stopped.

\section{Conclusions}

Phosphite is a useful management tool for controlling phytophthora diseases in natural and horticultural settings. All of the Phytophthora species in this study were inhibited by phosphite, but at different rates. The inter-specific variability of phosphite tolerance may mean that lower phosphite concentrations can be applied to more sensitive species, such as kauri to control $P$. agathidicida. The intra-specific variability shown in P. kernoviae and P. aleatoria suggests the need for screening isolates in vitro and in planta before applying phosphite to a new pathosystem without prior efficacy testing.

Acknowledgements This work was funded through the Strategic Science Investment funds from the New Zealand Ministry of Business Innovation and Employment (MBIE). Rita Tetenburg and Sara Carey are thanked for their work in processing cultures into the New Zealand Forest Research Institute Culture Collection. Mike Clearwater is acknowledged for supervising. Scion's Forest Protection Culture Collection maintains all the New Zealand isolates collected and used in this study.

Funding Open Access funding enabled and organized by CAUL and its Member Institutions.

\section{Declarations}

Conflicts of interest The authors declare there are no conflicts of interest.

Open Access This article is licensed under a Creative Commons Attribution 4.0 International License, which permits use, sharing, adaptation, distribution and reproduction in any medium or format, as long as you give appropriate credit to the original author(s) and the source, provide a link to the Creative Commons licence, and indicate if changes were made. The images or other third party material in this article are included in the article's Creative Commons licence, unless indicated otherwise in a credit line to the material. If material is not included in the article's Creative Commons licence and your intended use is not permitted by statutory regulation or exceeds the permitted use, you will need to obtain permission directly from the copyright holder. To view a copy of this licence, visit http://creativecommons.org/licenses/by/4.0/.

\section{References}

Beales PA, Giltrap PG, Payne A, Ingram N (2009) A new threat to UK heathland from Phytophthora kernoviae on Vaccinium myrtillus in the wild. Plant Pathol 58:393-393

Bradshaw RE, Bellgard SE, Black A, Burns BR, Gerth ML, McDougal RL, Scott PM, Waipara NW, Weir BS, Williams NM, Winkworth RC, Ashcroft T, Bradley EL, Dijkwel PP, Guo Y, Lacey RF, Mesarich CH, Panda P, Horner IJ (2020) Phytophthora agathidicida: research progress, cultural perspectives and knowledge gaps in the control and management of kauri dieback in New Zealand. Plant Pathol 69:3-16

Brasier CM, Beales PA, Kirk SA, Denman S, Rose J (2005) Phytophthora kernoviae sp nov., an invasive pathogen causing bleeding stem lesions on forest trees and foliar necrosis of ornamentals in the UK. Mycol Res 109:853-859

Burra DD, Berkowitz O, Hedley PE, Morris J, Resjö S, Levander F, Liljeroth E, Andreasson E, Alexandersson E (2014) Phosphiteinduced changes of the transcriptome and secretome in Solanum tuberosum leading to resistance against Phytophthora infestans. BMC Plant Biol 14:254 
Coffey MD, Bower LA (1984) In vitro variability among isolates of eight Phytophthora species in responce to phosphorous acid. Phytophathology 74:738-742

Crosby T, Dugdale J, Watt J (1998) Area codes for recording specimen localities in the New Zealand subregion. New Zealand Journal of Zoology 25:175-183

Dick MA, Williams NM, Bader MK-F, Gardner JF, Bulman LS (2014) Pathogenicity of Phytophthora pluvialis to Pinus radiata and its relation with red needle cast disease in New Zealand. NZ J Forest Sci 44:1-12

Dobrowolski MP, Shearer BL, Colquhoun IJ, O’Brien PA, Hardy GESJ (2008) Selection for decreased sensitivity to phosphite in Phytophthora cinnamomi with prolonged use of fungicide. Plant Pathol 57:928-936

Eshraghi L, Anderson J, Aryamanesh N, Shearer B, McComb J, Hardy GS, O’Brien P (2011) Phosphite primed defence responses and enhanced expression of defence genes in Arabidopsis thaliana infected with Phytophthora cinnamomi. Plant Pathol 60:1086-1095

Guest DI, Pegg KG, Whiley AW (2010) Control of phytophthora diseases of tree crops using trunk-injected phosphates. In: Horticultural Reviews. John Wiley \& Sons, Inc., pp 299-330

Hardy GESJ, Barrett S, Shearer BL (2001) The future of phosphite as a fungicide to control the soilborne plant pathogen Phytophthora cinnamomi in natural ecosystems. Australas Plant Pathol 30:133-139

Horner IJ, Hough EG (2013) Phosphorous acid for controlling Phytophthora taxon Agathis in kauri: glasshouse trials. New Zealand Plant Protection 66:242-248

Horner IJ, Hough EG, Horner MB (2015) Forest efficacy trials on phosphite for control of kauri dieback. New Zealand Plant Protection 68:7-12

Hüberli D, Tommerup IC, Dobrowolski MP, Calver MC, Hardy GE (2001) Phenotypic variation in a clonal lineage of two Phytophthora cinnamomi populations from Western Australia. Mycol Res 105:1053-1064

Hunter S, Williams N, McDougal R, Scott P, Garbelotto M (2018) Evidence for rapid adaptive evolution of tolerance to chemical treatments in Phytophthora species and its practical implications. PLOS ONE 13:15

Hunter SR (2018) Determining the risk of phosphite tolerance in Phytophthora species in New Zealand and the United States: a case study on the implications of long-term use of phosphite to control
Phytophthora cinnamomi in avocado (Persea americana). The University of Waikato, Hamilton, New Zealand, Masters

Lim S, Borza T, Peters RD, Coffin RH, Al-Mughrabi KI, Pinto DM, Wang-Pruski G (2013) Proteomics analysis suggests broad functional changes in potato leaves triggered by phosphites and a complex indirect mode of action against Phytophthora infestans. J Proteomics 93:207-223

Ma J, McLeod A (2014) In vitro sensitivity of South African Phytophthora cinnamomi to phosphite at different phosphate concentrations. South African Avocado Growers' Association Yearbook 37

Maechler M (2019) Finding Groups in Data": Cluster Analysis Extended Rousseeuw et. R package version 2

McDougal RL, Ganley RJ (2021) Foliar Phytophthora in New Zealand plantation forests: historical presence of Phytophthora kernoviae and association with a previously undiagnosed disorder of Pinus radiata. Australasian Plant Pathology

Ramsfield TD, Dick MA, Beever RE, Horner IJ, McAlonan MJ, Hill CF (2009) Phytophthora kernoviae in New Zealand. Paper presented at the Phytophthoras in Forests and Natural Ecosystems. Proceedings of the Fourth Meeting of the International Union of Forest Research Organizations (IUFRO) Working Party S07.02.09, Monterey, California

Ribeiro OK, Erwin DC, Zentmyer GA (1975) An improved synthetic medium for oospore production and germination of several Phytophthora species. Mycologia 67:1012-1019

Ritz C, Baty F, Streibig JC, Gerhard D (2016) Dose-Response Analysis Using R. PLOS ONE 10:e0146021

Rolando CA, Dick MA, Gardner J, Bader MKF, Williams NM (2017) Chemical control of two Phytophthora species infecting the canopy of Monterey pine (Pinus radiata). Forest Pathology 47

Scott P, Bader MKF, Burgess T, Hardy G, Williams N (2019) Global biogeography and invasion risk of the plant pathogen genus Phytophthora. Environ Sci Policy 101:175-182

Smillie R, Grant B, Guest D (1989) The mode of action of phosphite: evidence for both direct and indirect modes of action on three Phytophthora spp. in plants. Phytopathology 79

Vernière C, Cohen S, Raffanel B, Dubois A, Venard P, Panabières F (2004) Variability in Pathogenicity among Phytophthora spp. Isolated from Citrus in Corsica. J Journal of Phytopathology 152:476-483

Wilkinson CJ, Shearer BL, Jackson TJ, Hardy GESJ (2001) Variation in sensitivity of Western Australian isolates of Phytophthora cinnamomi to phosphite in vitro. Plant Pathol 50:83-89 